\title{
THE MURRAY GOLD DISTRICT, SHOSHONE COUNTY, IDAHO: A POSSIBLE REDUCED
}

INTRUSION-RELATED GOLD SYSTEM

\section{.}

Introduction

The Murray gold district is located in northern Idaho on the northern edge of the Coeur d'Alene Pb-Zn-Ag mining district (Figure 1). The largest mine in the Murray district is the Golden Chest, operated by New Jersey Mining Company (NJMC). The southeastern edge of the district is intruded by several small, mid Cretaceous monzonite intrusions known as the Gem and Dago Peak stocks.

Previous exploration of the Golden Chest mine has been based on an orogenic model (NJMC Golden Chest 43-101, 2012). However, the Golden Chest mine and Murray district appear to have some of the characteristics of a reduced intrusion related gold system (RIRGS)

\section{Reduced Intrusion-related gold system}

Reduced Intrusion-related gold systems (RIRGS) are a recently recognized (e. Sillitoe \& Thompson, 1998; Hart 2007) class of deposit similar to, though distinct from, orogenic deposits. The following table compares characteristics of The Murray district to the RIRGS type deposits associated with the Alaska-Yukon Tombstone plutonic suite where the class was defined:

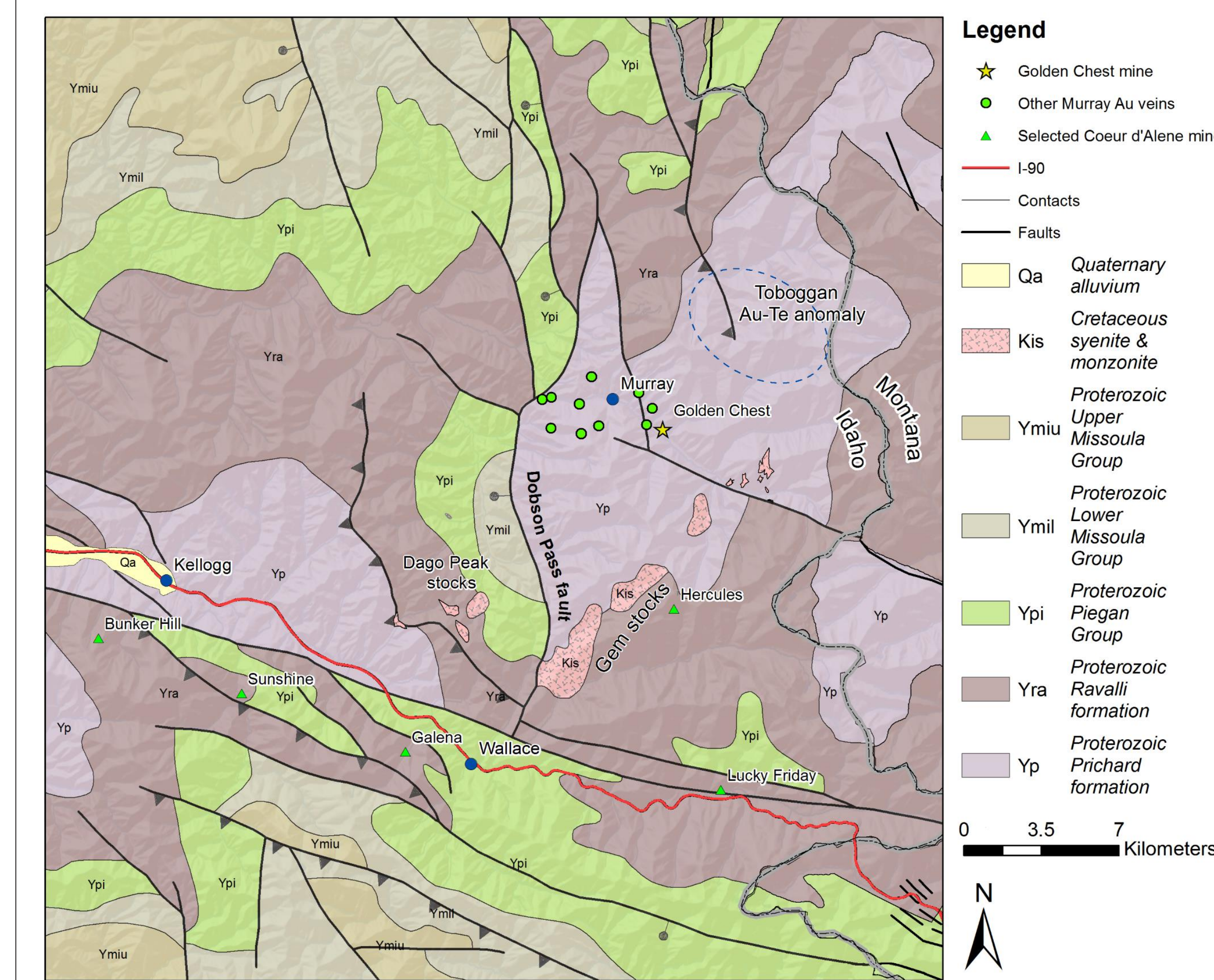

Figure 1: Geology of the Murray area

Golden Chest Mine and Murray District The Gem stocks are small and elongate. Composition grades from
diorite to syenite. Predominantly hornblende monzonite. Two analyses available: one is weakly peraluminous, the other moderately. Association with small, elongate, metaluminous to weakly peraluminous intrusions of intermediate to felsic composition

Associated plutons are moderately reduced I-type and lie near the boundary between the ilmenite and magnetite series.

Plutons have abundant evidence of hydrothermal and mineralizing fluids such as high volatile content, evidence of fractionation and fluid exsolution, associated skarns, aplite and pegmatite dikes, tourmaline
veins, greisen etc

Hydrothermal fluids are highly variable but generally low salinity mixed $\mathrm{CO}_{2}-\mathrm{H}_{2} \mathrm{O}$ fluids

RIRGS exhibit diverse deposit styles and commonly have a zonation of metals

The monzonite is I-type and contains accessory magnetite.

The Gem stocks have associated skarn deposits, and aplite dikes.

of tourmaline are eported from the aureole though not as veins.

Fluid inclusions from mineralogically similar Au-Qtz veins near Kelloge verage $17 \% \mathrm{CO}_{2}, 22 \% \mathrm{NaCl}$ equiv.

Gold in the area is found mostly as sheeted, bedding parallel quartz veins and in quartz breccias, but also in shear veins, in certain $\mathrm{Pb}-\mathrm{Zn}$ veins and in $\mathrm{Sb}$-Au veins. There is an apparent zonation from basemetal rich Cretaceous deposits near the Gem stocks to the Murray gold veins and further north the Te-rich Toboggan deposit.

Metal assemblage variably combines gold with elevated $\mathrm{Bi}, \mathrm{W}, \mathrm{As}, \mathrm{Mo}$ Te, and/or Sb and low concentrations of base metals

A low sulfide mineral content, mostly $<5$ vol\%, with a reduced ore mineral assemblage that typically comprises arsenopyrite, pyrrhotite and pyrite and lacks magnetite or hematite

Areally restricted, commonly weak hydrothermal alteration

A tectonic setting well inboard of inferred or recognized convergent plate boundaries

A location in magmatic provinces known for tungsten and/or tin deposits

Mineralization is the same age or slightly younger than associated intrusives. Veins may cut their parent intrusion.
Arsenopyrite is common at Golden Chest and Te is found at the Toboggan prospect to the north. Tentative tungstibite $\left(\mathrm{Sb}_{2} \mathrm{WO}_{6}\right)$ found at Golden Chest. Golden Chest is a historic W producer; $W$ found at several mines and prospects within appx. $5 \mathrm{Km}$ radius around Murray.

Arsenopyrite and pyrite are common. Scattered pyrrhotite. Total sulfides no more than a few percent.

Alteration around the Gem stocks is limited. At Golden Chest alteration is generally weak chloritization and silicification restricted to within a few meters of the vein

Gem stocks would have been in back arc to Idaho Batholith volcanism and inboard of the $0.706^{87} \mathrm{Sr} /{ }^{86} \mathrm{Sr}$ line. vein, minor $W$ in modern workings and scattered scheelite area.

Gem stocks have conflicting age dates of $94 \pm 10 \mathrm{Ma}$ and $116 \pm 10 \mathrm{Ma}$ from zircon and $131 \pm 4 \mathrm{Ma}$ and $137 \pm 4 \mathrm{Ma}$ from hornblende. There are no published ages for the Murray Au veins but isotopically identical (though more sulfide-rich) veins in the northern Belt-Purcell basin are Cretaceous
Golden Chest produced $\mathrm{W}$ during the First World War from Katie-Dora occurrences in adjacent mines and prospects. No tin is reported in the

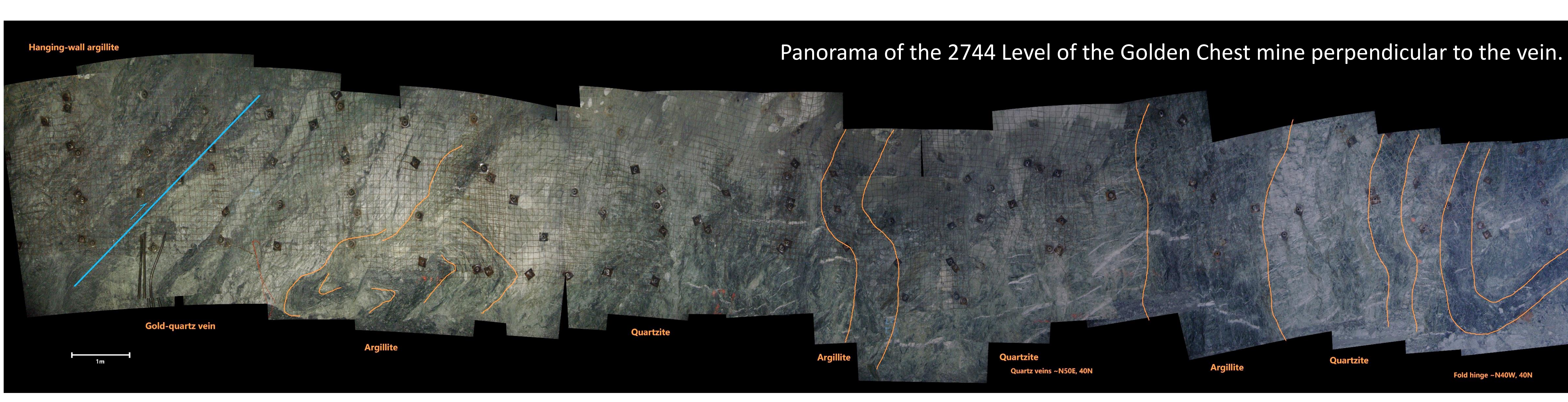

Differences between the RIRGS type locality and the Murray district

Some of the features of the Murray sub-district differ from the RIRGS type localities in Alaska-Yukon Tombstone belt:

$$
\begin{aligned}
& \text { Gem stocks are more magnetite-rich than the Tombstone suite } \\
& \text { No intrusive-hosted Au mineralization or Au skarns known } \\
& \text { Pb-Zn veins found close to the Gem stocks } \\
& \text { Minimal Bi found in the Murray district }
\end{aligned}
$$

The plutons of the Tombstone suite generally lack magnetite and have low magnetic susceptibilities compared to their aureole whereas the Gem stocks have accessory magnetite and higher magnetic susceptibilities than their surroundings. Base metal veins near the Gem contacts contain abundant magnetite. Leach et al (1998) noted that these veins are deformed and suggested the vein magnetite formed by metamorphism of Proterozoic siderite-sphalerite veins. Similarly, Parkinson (1984) suggested that deuteric reactions could have produced at least some of the disseminated magnetite. While it is unlikely that all of the magnetite is secondary, the Gem stocks may have initially been closer to the ilmenite-magnetite series boundary.

The majority of RIRGS are hosted within the plutons as numerous parallel quartz veinlets to $10 \mathrm{~cm}$ wide which form low-grade, bulkminable deposits like Fort Knox. However, there are a few described deposits where the mineralization is found as fewer, large highgrade veins more distal from the pluton such as the Ryan Lode in Alaska. If the Golden Chest and other Murray veins are related to the Gem stocks, they are the less common Ryan Lode type.

Another problem for the RIRGS hypothesis is the "reverse" zoning. In the Tombstone suite, Ag-Pb-Zn veins are the most distal expression of mineralization whereas at Murray base metals are found close to the Gem stocks. The bulk of the Murray base metal skarn and vein deposits are remobilized Proterozoic material but a number of prospects contain Cretaceous lead so the zoning is not entirely due to preexisting mineralization. Similarly, in most of the reported RIRGS, Bi is closely correlated with Au. The Toboggan deposit northeast of Murray contains locally elevated Bi but is distal to the Gem stocks, Bi has not been reported from the deposits closer to the intrusions. However in the RIRGS model deposits, elevated Bi is more often associated with Au hosted within the pluton itself.

\section{Conclusions and further exploration}

While the Murray veins do not completely match the reduced intrusion model, there do appear to be some similarities between the RIRGS model and the Cretaceous intrusions of northern Idaho and southern British Columbia.

The key assumption of the RIRGS model is that the pluton and mineralizing system are coeval. Detailed geochronological study of the Gem stocks and Murray veins would be a straightforward test to see if the RIRGS model could be applicable to the Murray district.

If further dating and geochemical analysis are consistent with a RIRGS deposit, Local exploration focusing on structures that may have carried fluids away from the intrusions as well as the upper plate of the Dobson pass fault east of Kellogg may be productive. The model may also allow selection of a geochemical exploration suite that may not have been employed in previous exploration programs.

On a larger scale, small syenite-monzonite stocks of Middle Cretaceous age intrude Proterozoic sediments in a belt extending from Gold Hill north of Moscow, ID up to Wall Mountain near Bonners Ferry, ID (Figure 3). With the possible exception of the syenite stock on the Montana-ldaho border northeast of Hope, ID, these intrusions are associated with historic gold-tungsten production. Logan et al. (2000) identified a suite of similar Cretaceous syenite intrusions associated with RIRGS in southeastern British Columbia. The Idaho intrusions may be a southern extension of this same RIRGS belt

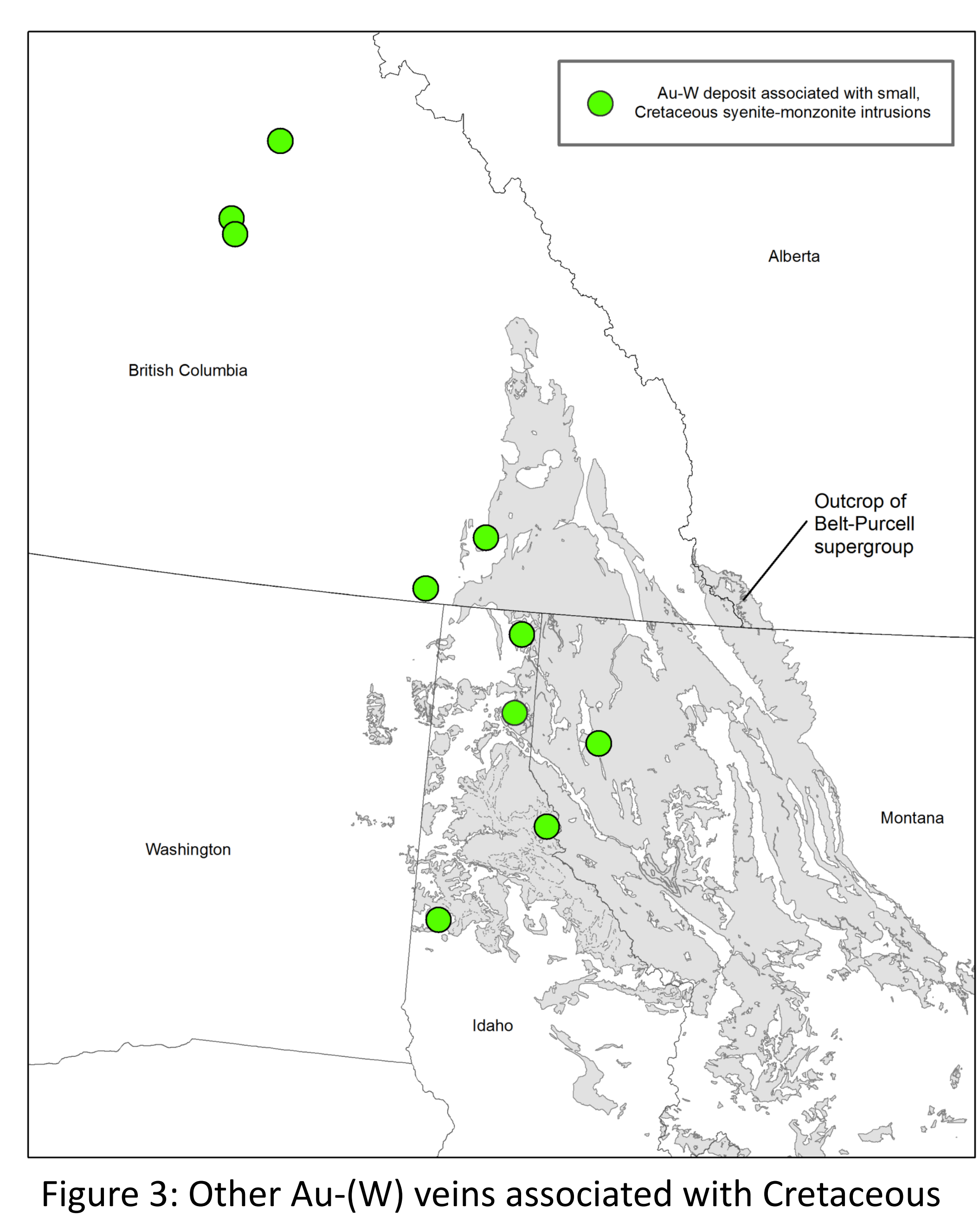

Acknowledgements 